\title{
Can Big Fish in a Small Pond Also Swim Happily? The Influence of Perceived Overqualification on Career Success
}

\author{
Yuanyuan Yu, Maolin Ye* \\ Management School, Jinan University, Guangzhou, China \\ Email: *maolinye@163.com
}

How to cite this paper: Yu, Y.Y. and Ye, M.L. (2019) Can Big Fish in a Small Pond Also Swim Happily? The Influence of Perceived Overqualification on Career Success. Open Journal of Social Sciences, 7, 1-12. https://doi.org/10.4236/jss.2019.73001

Received: February 11, 2019

Accepted: March 3, 2019

Published: March 6, 2019

Copyright (อ 2019 by author(s) and Scientific Research Publishing Inc. This work is licensed under the Creative Commons Attribution International License (CC BY 4.0).

http://creativecommons.org/licenses/by/4.0/

\section{(c) (i) Open Access}

\begin{abstract}
Building on the conservation of resource theory, this study tries to examine the effect of perceived overqualification (POQ) on career success as well as the associated underlying mechanism. Specifically, our study proposed a moderated mediation model in which perceived overqualification influenced career success through job crafting, and career concern was served as the first-stage moderator. All hypotheses were tested. We collected the data from 195 full-time employees from the MBA classes in China, using a series of regression analysis combined with bootstrapping method. Four conclusions were obtained: 1) POQ was positively related to objective and subjective career success; 2) Such relationships were partially mediated by job crafting; 3 ) Career concern moderated the relationship between POQ and job crafting, such that the higher the employees' career concern, the stronger positive relationship between POQ and job crafting; 4) Career concern moderated the mediating effect of job crafting on the relationship between POQ and career success, such that this effect was stronger when employees' career concern was high.
\end{abstract}

\section{Keywords}

Perceived Overqualification, Career Success, Job Crafting, Career Concern

\section{Introduction}

According to a global labor market survey by Canadian, more than $80 \%$ Chinese thought that they wasted their talent on a petty job. Academically, this phenomenon is called perceived overqualification (POQ), which refers to the perception that one is working in a job that requires a lesser degree of education, experience, and knowledge, skills, and abilities (KSAs) than what one possesses [1]. 
In fact, POQ and objective overqualification have relationship, but they have distinctive constructs. Objective overqualification compares levels of ability and preparation to the demands of the job [2], while POQ deals with employees' feelings of being overqualified. We know that perceptions affect individual's behavior, so it is critical to learn more about POQ.

Previous studies are based on the relative deprivation theory, equity theory, and have suggested that POQ can have negative effects [1] [3]. However, in recent years, some scholars have proposed that POQ can stimulate positive behaviors and bring about a good result. Moreover, positive oriented individuals are more likely to take positive measure [4] [5].

In the era of traditional career, the organizational structure of the enterprise is stable and adopts centralized management. Employees have limited career and job options, which results in a series of negative consequences when people cannot use their talents. However, with the advent of the "Borderless Career Age", career turbulence is complex [6]. Employment uncertainty has increased, and employees' job security decreased significantly. It is urgent to improve individual employability by enlarging knowledge reserve and learning more skills [7]. For those employees who have high level of POQ, they can find new work content in line with their interests in a flexible organization. They can also find a platform for releasing their talents, and gain the appreciation from others and achieve career success. Therefore, in the context of the new era, whether there will be new changes in the work behaviors for employees' with POQ needs to be further studied.

Secondly, most previous studies regarded people as "economic animals" and believed that people's behaviors were all to satisfy their personal interests, and they only wanted to get economic rewards. Therefore, most research results believed that the high level of POQ had a negative influence. Based on the hypothesis of social person and the theory of resource preservation and career construction, this study holds that people have the ability and motivation to actively seek self-realization, acquire resources and construct their own career, and may show more positive behaviors.

The conservation of resource theory points out that when individuals are under less pressure, they will have the tendency to obtain resources. Through this process, resources that can offset the possible loss of resources in the future can be accumulated [8]. Because employees with higher POQ think that their ability surpasses the job requirement, and they can complete task quicker and better. Therefore, they have much time and energy resources left which can be invested [4]. In addition, through this process, one can acquire more types and quantities of resources. Career success can bring various and abundant resources, but previous studies have neglected to explore the relationship between POQ and career success. In addition, more questions need further research, like what type of employees will adopt positive measures to cope with their POQ and how to achieve career success. Agut, Peiro and Grau (2009) believe that individuals with high POQ may achieve Person-job Fit through job crafting, which is lack empirical 
support [9].

In addition, the theory of resource preservation also points out that when individuals attach importance to future resources, they will be willing to invest in existing resources [8].

Therefore, this study will explore the mediating mechanism of job crafting in individual's POQ and subjective and objective career success, and the role of career concern in job crafting behavior of individuals with higher POQ.

\section{Theory and Hypotheses}

\subsection{POQ and Career Success}

According to the conservation of resource theory, one tends to maintain, protect and construct resources, and one may invest his existing resources to obtain other types of resources [8]. There are four types of resources. Object resources refer to the physical attributes and benefit of resources, such as money, information and services. Conditional resources refer to resources that can create conditions for obtaining other important resources, such as good connections. Personal characteristics refer to resources that help individuals to resist pressure, such as values, self-efficacy, and capacity. Energy resources refer to resources that used to achieve other resources, such as time, knowledge. Career success can bring diverse and abundant resources. Previous studies have shown that career success is strongly associated with higher compensation level, more frequent promotions [10], and can improve individual social relations and subjective well-being [11].

However, it is clear that in order to achieve career success, individuals must first invest in resources. Abundant human capital (working experience, working years, knowledge and skills), social capital and psychological capital are conducive to individual career success [12] [13]. In order to achieve career success, individuals must pay their own resources (time, experience, knowledge and skills). Maltarich, Nyberg and Reilly (2010) argue that individuals with POQ are not deprived. They have surplus resources to do more things, such as developing interests and continuing education [14].

Therefore, employees with higher POQ can complete their current work easily [4], so they have stronger sense of self-efficacy and competence [5], which helps them experience subjective career success. At the same time, these employees can use their energy resources (such as more attention and time) to carry out additional learning and skills upgrading [2], which helps them achieve objective career success.

On the contrary, employees with lower POQ have only slightly higher self-ability than job requirements, which means that they have lower sense of competence and self-efficacy [5]. In addition, they need more time and energy in dealing with their routine tasks. This pressure drives them to make it a priority to protect existing resources instead of consuming existing resources in exchange for other resources, which is not be not good for them to achieve subjective and objective career success. Accordingly, hypothesis 1 is proposed in this 
study:

$\mathrm{H} 1 \mathrm{a}$ : POQ is positively related to subjective career success.

H1b: POQ is positively related to objective career success.

\subsection{The Mediation Role of Job Crafting}

Job crafting has been defined as "self-initiated change behaviors that employees engage in with the aim to align their jobs with their own preferences, motives, and passions" [15], which can help individuals obtain resources, reduce work boredom and bring a sense of work significance. There are four kinds of job crafting-increasing structural job resources, increasing social job resources, increasing challenging job demands and decreasing hindering job demands.

Among them, increasing structural job resources refer to one acquires more work autonomy or learn more knowledge, such as initiative to participate in training, learning new skills, which help to obtain individual idiosyncratic resources and enrich human capital. Increasing social job resources refer to interaction with supervisors and colleagues, such as seeking feedback and guidance from supervisors actively, seeking support from supervisors and colleagues, which can enrich conditional resources and social capital. Increasing challenging job demands refer to one volunteers for more difficult work, so that he can learn more knowledge [16], gain a sense of self-efficacy [17], and fully demonstrate his abilities, which help to supplement individual idiosyncratic resources, conditional resources, and obtain more psychological capital at the same time. Decreasing hindering job demands refer to individuals to reduce duplicate and ineffective work actively, which increase the available resources for investment by reducing consumption of existing resources.

Based on the conservation of resource theory, for individuals with high POQ, their time, energy and resources are relatively abundant [2], but the structure of resources is unbalanced. So they tend to obtain multiple resources through job crafting. Career success is the goal that employees eager to achieve in somebody's professional career. Employees with POW are no exception. Through job crafting, human capital, social capital and psychological capital have been supplemented and enriched, which is conducive to individual career success. Therefore, those with higher POQ may be able to achieve career success through job crafting; on the contrary, due to greater work pressure, individuals with lower POQ tend to have a strong sense of resource loss, which result in the tendency to protect existing resources, and thus have lower enthusiasm for job crafting. Accordingly, hypothesis 2 is proposed in this study.

H2a: POQ has an indirect effect on subjective career success through job carfting, in that POQ has a positive relationship with job crafting and job crafting has a positive relationship with subjective career success.

H2b: POQ has an indirect effect on objective career success through job crafting, in that POQ has a positive relationship with job crafting and job crafting has a positive relationship with objective career success. 


\subsection{The Moderation Role of Career Concern}

The theory of resource conservation holds that individuals will view the investment and return of resources from a long-term perspective [8]. In the short term, job crafting is time-consuming and laborious. For instance, individuals need to take time to participate in training, pay emotions and build good relationships with leaders and colleagues. However, long-term, job crafting will help individuals to acquire abundant resources in the future, such as ability improvement and harmonious workplace relations. Savickas and Porfeli (2012) argue that career concern refers to the individual's concern for his future career, which help somebody to concentrate on the future [18]. Career concern is an individual's ability resource, which can provide energy for individuals to pursue better career development.

Therefore, this study holds that individuals with high level of career concern will have a longer-term career planning [19] and pay more attention to resource acquisition in the future. Therefore, they are more likely to invest their current resources and show more job crafting behavior for resource acquisition. On the other hand, these employees have more energy resources to invest. On the contrary, employees with low level of career concern may likely focus on recent resource depletion and acquisition. They regard short-term resource depletion as a great threat. Therefore, their primary task is to protect existing resources and refuse to pay resources for the future. Therefore, they may show less job crafting behavior. Accordingly, hypothesis 3 is proposed in this study.

H3: Career concern moderates the positive relationship between POQ and job crafting, such that it is stronger when the level of career concern is higher.

Integrating the above hypotheses, hypothesis 4 is proposed in this study.

H4: Career concern moderates the indirect effect of POQ on subjective and objective career success through job crafting, such that the indirect effect is more positive when the level of career concern is higher than when it is low.

\section{Sample and Measures}

Participants were MBA students from five universities, in which two in Guangdong and three in Shandong in China. In order to avoid homologous variation, data were collected at three time points, and were matched by their student number. At time 1, the employees were asked to report their demographic information, POQ and career concerns. Two weeks later (Time 2), they were asked to report their job crafting. Two weeks after Times 2 (Time 3), they were asked to report their subjective and objective career success. A total of 270 questionnaires were distributed. After deleting blanks and filling in invalid questionnaires, the final sample consisted of 195 questionnaires. Among them, 85 $(43.6 \%)$ were males. Their mean age was $34.47(S D=8.86)$, and their average length of education was $15.63(S D=1.91)$. Their average organizational tenure was 8.88 years $(S D=9.14)$. $76(39 \%)$ of them were ordinary employees, 72 (36.9\%) were first-level managers, 42 (21.5\%) were middle managers, 5 (2.6\%) 
were senior managers.

All scales were translated and back-translated from English to Chinese. All of the items were measured by 5-point Likert scales anchored from 1 (strongly disagree) to 5 (strongly agree).

POQ: The 9-items qualification developed by Fine and Nevo (2008) has two dimensions-cognitive mismatch and cognitive growth [20]. By using confirmatory factor analysis, the model fitted well (RMSEA $=0.07, \mathrm{CFI}=0.96, \mathrm{NNFI}=$ 0.93 , SRMR $=0.05$ ) after deleting one item whose factor load was less than 0.40 . In this study, cronbach's alpha was 0.75 .

Job crafting: The 21-items qualification developed by Tims, Bakker and Derks (2012) has four dimensions [21]. Among them, there are 5 items for increasing structural job resources, increasing social job resources and increasing challenging job demands. By using confirmatory factor analysis, the model fitted well $(\mathrm{RMSEA}=0.04, \mathrm{CFI}=0.97, \mathrm{NNFI}=0.96, \mathrm{SRMR}=0.05)$ after deleting 2 items whose factor load was lower than.40. In this study, cronbach's alpha was 0.89 .

Subjective career success: The 5 -items qualification developed by Greenhaus, Parasuraman and Wormley (1990) has one dimension [22]. Confirmative factor analysis showed that the model fitted well $(\mathrm{RMSEA}=0.00, \mathrm{CFI}=1.00, \mathrm{NNFI}=$ 1.00$, SRMR $=0.01)$. In this study, cronbach's alpha was 0.87 .

Objective Career Success: The 6-items qualification developed by Eby, Butts and Lockwood (2003) has two dimensions-internal competitiveness and external competitiveness [23]. The confirmatory factor analysis showed that the model fitted well (RMSEA $=0.06$, CFI $=0.99$, NNFI $=0.98$, SRMR $=0.02$ ). In this study, cronbach's alpha was 0.85 .

Career Concern: The 6-items qualification for Chinese situations developed by Hou et al. (2012) has one dimension [24]. Confirmative factor analysis showed that the model fitted well $(\mathrm{RMSEA}=0.04, \mathrm{CFI}=0.99, \mathrm{NNFI}=0.99, \mathrm{SRMR}=$ 0.02 ). In this study, cronbach's alpha was 0.86 .

Control variables: Following previous research, we chose gender, age, length of education, tenure and position as control variables [25] [26].

\section{Analyses and Results}

\subsection{Descriptive Statistics and Correlation Analysis}

We used SPSS 23.0 and Mplus 7.4 to process the data.

Descriptive statistics and related analysis are shown in Table 1. POQ is positively correlated with job crafting $(r=0.25, P<0.01)$, subjective career success $(r$ $=0.28, \mathrm{P}<0.01)$ and objective career success $(\mathrm{r}=0.27, \mathrm{P}<0.01)$. Job crafting is positively correlated with subjective career success $(\mathrm{r}=0.40, \mathrm{P}<0.01)$ and objective career success $(\mathrm{r}=0.46, \mathrm{P}<0.01)$.

\subsection{Common Method Biases Test}

In order to control the deviation of the common method, this study carried out control in the process of testing, that is, collecting data at three time points, re- 
duced the influence of homologous variation to a certain extent. In addition, Harman single factor method was used to test the homologous variance [27]. Exploratory factor analysis showed that the variance explained by the first factor without rotational precipitation was $10.62 \%$, which was less than half of the total variance (64.24\%). It means that the deviation of common methods will not cause serious impact in this study.

\subsection{Hypothesis Test}

Hierarchical regression was used to test hypothesis in this study, and the results are shown in Table 2 . Model 3 showed that POQ significantly positively predicted individual's subjective career success $(\beta=0.36, \mathrm{P}<0.001)$; Model 5 showed that $\mathrm{POQ}$ significantly positively predicted individual's objective career success $(\beta=0.33, \mathrm{P}<0.001)$, so hypothesis H1a and H1b were supported.

Model 1 showed that POQ significantly positively predicted individual job carfting $(\beta=0.25, \mathrm{P}<0.01)$. Model 4 showed that job carfting has a significant positive effect on individual's subjective career success $(\beta=0.44, \mathrm{P}<0.001)$. And the positive effect of POQ on subjective career success is still significant $(\beta=$ $0.25, \mathrm{P}<0.01)$. Therefore, job crafting partially mediates the relationship between POQ and subjective career success (intermediary effect $=12$, bias correction CI95\% $=[0.05,0.21])$. Similarly, model 1 and Model 6 also supported the mediation role of job crafting between POQ and objective career success (mediating effect $=0.14$, bias correction CI $95 \%=[0.07,0.25]$ ). Therefore, hypothesis $\mathrm{H} 2 \mathrm{a}$ and $\mathrm{H} 2 \mathrm{~b}$ were supported.

In addition, model 2 showed that the interaction between POQ and career concern significantly positively predicted job crafting $(\beta=0.33, \mathrm{P}<0.01)$. Figure 1 shows the interaction between POQ and career concerns affecting job crafting. Simple slope analysis showed that when the level of career concern was high, individuals with POQ will show more job crafting behavior $(\beta=0.43, \mathrm{P}<0.001)$; and when the level of career concern was low, POQ will not affect job crafting behavior $(\beta=-0.04, n s)$. Therefore, hypothesis 3 is supported.

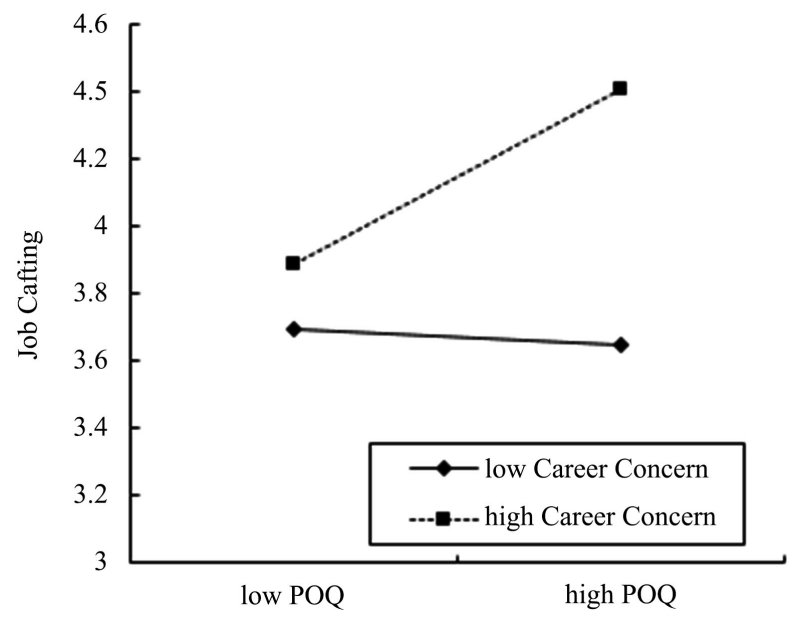

Figure 1. Moderating effect diagram of career concern. 
Table 1. Variable descriptive statistics and relevant analysis results.

\begin{tabular}{|c|c|c|c|c|c|c|c|c|c|c|c|}
\hline Variables & $M$ & $S D$ & 1 & 2 & 3 & 4 & 5 & 6 & 7 & 8 & 9 \\
\hline 1) Gender & 0.56 & 0.50 & - & & & & & & & & \\
\hline 2) Age & 34.47 & 8.86 & $-0.26^{\star * *}$ & - & & & & & & & \\
\hline 3) Education & 15.63 & 1.91 & 0.13 & -0.09 & - & & & & & & \\
\hline 4) Tenure & 8.88 & 9.14 & $-0.15^{*}$ & $0.82^{\star * *}$ & -0.10 & - & & & & & \\
\hline 5) Position & 1.88 & 0.83 & $-0.21^{\star *}$ & 0.11 & 0.03 & 0.05 & - & & & & \\
\hline 6) $P O Q$ & 3.32 & 0.59 & 0.01 & -0.06 & -0.08 & -0.05 & 0.08 & - & & & \\
\hline 7) Job Cafting & 3.49 & 0.61 & -0.93 & $-0.16^{*}$ & -0.07 & -0.13 & 0.44 & $0.25^{* * *}$ & - & & \\
\hline $\begin{array}{l}\text { 8) Career } \\
\text { Concern }\end{array}$ & 3.93 & 0.73 & 0.04 & $-0.28^{* * *}$ & -0.04 & $-0.27^{\star * *}$ & 0.01 & $0.19^{* *}$ & $0.40^{\star * *}$ & - & \\
\hline $\begin{array}{l}\text { 9) Subjective } \\
\text { Career Success }\end{array}$ & 3.68 & 0.77 & -0.02 & -0.09 & 0.01 & $-0.17^{*}$ & 0.09 & $0.28^{\star * *}$ & $0.40^{* * *}$ & $0.43^{* * *}$ & - \\
\hline $\begin{array}{l}\text { 10) Objective } \\
\text { Career Success }\end{array}$ & 3.58 & 0.79 & -0.01 & -0.07 & -0.08 & -0.08 & 0.11 & $0.27^{\star * \star}$ & $0.46^{* * *}$ & $0.45^{\star * *}$ & $0.54^{* * *}$ \\
\hline
\end{tabular}

Note: $N=195 ;{ }^{*} p<0.05 ;{ }^{*} p<0.01 ;{ }^{* *} p<0.001$.Sex: $1=$ male, $0=$ female, Education: $6=$ Primary school, $9=$ Junior high school, $12=$ Senior high school, 15 = Junior college, $16=$ Undergraduate, $19=$ Graduate, and $22=$ Doctor. Position: $1=$ Ordinary employee, $2=$ Low-level manager, $3=$ Middle manager, 4 = Senior manager.

Table 2. Hierarchical regression results.

\begin{tabular}{|c|c|c|c|c|c|c|}
\hline \multirow{2}{*}{ Variables } & \multicolumn{2}{|c|}{ Job Crafting } & \multicolumn{2}{|c|}{ Subjective Career Success } & \multicolumn{2}{|c|}{ Objective Career Success } \\
\hline & M1 & M2 & M3 & M4 & M5 & M6 \\
\hline Intercept & $3.50^{* * *}$ & $3.91^{* * *}$ & $2.09^{* *}$ & 0.53 & $2.84^{\star * *}$ & 0.91 \\
\hline \multicolumn{7}{|l|}{ Control Variables } \\
\hline Gender & -0.17 & -0.12 & -0.03 & 0.05 & 0.01 & 0.11 \\
\hline Age & -0.02 & -0.01 & 0.00 & 0.02 & -0.00 & 0.01 \\
\hline Education & -0.02 & -0.00 & 0.01 & 0.01 & -0.03 & -0.02 \\
\hline Tenure & 0.00 & 0.01 & $-0.02^{*}$ & $-0.02^{*}$ & -0.01 & -0.01 \\
\hline Position & 0.02 & 0.05 & 0.06 & 0.05 & 0.09 & 0.08 \\
\hline \multicolumn{7}{|l|}{ Independent Variables } \\
\hline POQ & $0.25^{\star *}$ & $0.20^{* *}$ & $0.36^{* * *}$ & $0.25^{\star *}$ & $0.33^{\star * *}$ & $0.20^{*}$ \\
\hline \multicolumn{7}{|l|}{ Intervening variable } \\
\hline Job Cafting & & & & $0.44^{* * *}$ & & $0.55^{\star * *}$ \\
\hline \multicolumn{7}{|l|}{ Moderator variable } \\
\hline Career Concern & & $0.33^{* * *}$ & & & & \\
\hline \multicolumn{7}{|l|}{ Interaction effect } \\
\hline POQ $\times$ Career Concern & & $0.33^{* *}$ & & & & \\
\hline$R^{2}$ & 0.11 & 0.26 & 0.12 & 0.22 & 0.09 & 0.25 \\
\hline$\Delta R^{2}$ & - & 0.15 & - & 0.11 & - & 0.16 \\
\hline$F$ & $3.84^{\star *}$ & $19.27^{\star * *}$ & $4.05^{\star *}$ & $26.48^{\star * *}$ & $3.13^{* *}$ & $40.28^{\star * *}$ \\
\hline
\end{tabular}

Note: The non-standardized regression coefficients in the table are. ${ }^{\star} \mathrm{P}<0.05 ;{ }^{* *} \mathrm{P}<0.01 ;{ }^{* *} \mathrm{P}<0.001$. The related variables have been centralized. $\mathrm{N}=195$; ${ }^{*} \mathrm{p}<0.05 ;{ }^{* *} \mathrm{p}<0.01 ;{ }^{* *} \mathrm{p}<0.001$. Sex: $1=$ male, $0=$ female, Education: $6=$ Primary school, $9=$ Junior high school, $12=$ Senior high school, $15=$ Junior college, $16=$ Undergraduate, $19=$ Graduate, and $22=$ Doctor. Position: $1=$ Ordinary employee, $2=$ Low-level manager, $3=$ Middle manager, $4=$ Senior manager. 
Based on this model, we also examined the conditional indirect effect following recommendations by Hayes (2013) [28]. Specifically, for high levels of career concern, the indirect effect of POQ on subjective career success through job crafting was significant (conditional indirect effect $=0.20$, Boot $95 \% \mathrm{CI}=[0.09$, $0.36]$ ), and the indirect effect on objective career success was also significant (conditional indirect effect $=0.25$, Boot $95 \% \mathrm{CI}=[0.14,0.38]$ ). However, for low level of career concern, the indirect effects were not significant (subjective career success: conditional indirect effect $=-0.02$, Boot $95 \% \mathrm{CI}=[-0.12,0.06]$; objective career success: conditional indirect effect $=-0.02$, Boot $95 \% \mathrm{CI}=[-0.14$, $0.08]$ ). Therefore, the results support hypothesis H4.

\section{Discussion}

\subsection{Theoretical Significance}

Firstly, career success is an important issue in the field of organizational management. In the past, scholars mainly discussed the relationship between employee's human capital, social capital, psychological capital and career success based on career construction theory, social capital theory and self-determination theory. This paper chooses the perspective of resource preservation theory to further exploration the impact of POQ on career success, enriching the research on the causes of career success and theoretical perspective.

Secondly, Western scholars have found that subjective and objective overqualifications belong to two different concepts [2] [29], which may bring different results [29]. Objective overqualifications are prone to induce negative results, while POQ may bring positive results. This paper further finds out the positive relationship between POQ and career success. On the one hand, it provides an empirical basis for the views of Western scholars; on the other hand, it enriches the research on the consequences of POQ.

Thirdly, this paper also explores the intermediate mechanism for the overqualified to achieve career success, and explains the internal reasons for the overqualified to achieve career success from the perspective of resource preservation. The conclusion of the study is in agreement with the previous view that the overqualified people do not negatively cope with the mismatch between people and work, but will redesign their work [2] or innovate their work content [9].

Fourthly, this study also found that in order to achieve career success goals, those with high career concern can get personal career development through job crafting. This not only reveals the boundary conditions of POQ affecting job crafting, but also agrees with previous scholars that individuals with high career concern have a clear sense of preparation for the future, which can help them consider their current career and plan for their future career [19]. Individuals can recognize the differences between their current and future career situations and take active action to change their current situation [30].

\subsection{Practical Significance}

In addition to theoretical significance, this study can also provide some practical 
enlightenment. This study finds that career concerns can enhance the job remodeling behavior of the overqualified. Therefore, the organization can manage and train the employees with POQ from the following points.

First, the organization should do a good job of career management to enhance employees' career concerns, and urge employees to consciously pay attention to the future, and increase their curiosity about themselves and the surrounding environment, accelerate their career exploration, and let employees build confidence in choosing the future.

Second, it can give employees career development. Training, through the establishment of reasonable future goals, provides clear promotion path for employees, helps employees with strong POQ to establish career preferences, establish life themes, and strive to achieve goals.

\subsection{Deficiencies and Prospects}

Admittedly, there are still limitations and shortcomings in this study. Firstly, the objective career success was measured by self-evaluation. Although Eby et al. (2003) considered that objective career success is an individual's perception of his own workplace competitiveness and an individual can judge it by himself [23], we believe that future research can consider increasing his or her evaluation or objective data in order to further improve the credibility of the conclusions. Secondly, this paper only explores the relationship between subjective overqualifications and career success. The other side of overfunding, that is, objective career success, is not included in the model. Future research can be further explored from this perspective. Thirdly, this study examines the moderating effect of career concerns, and other boundary conditions need further study. For example, those with high level of POQ have more spare time and energy, so they are more likely to put that time and energy into jobcrafting if with high level of word centrality. For another example, employees with high core self-evaluation are more confident to change the status quo, so they are more inclined to reshape their work in the face of the situation of POQ.

\section{Conclusion}

Building on the conservation of resource theory, this study tries to examine the effect of perceived overqualification on career success as well as the associated underlying mechanism. Specifically, four conclusions were obtained: 1) POQ was positively related to objective and subjective career success; 2) Such relationships were partially mediated by job crafting; 3) Career concern moderated the relationship between POQ and job crafting, such that the higher the employees' career concern, the stronger positive relationship between POQ and job crafting; 4) Career concern moderated the mediating effect of job crafting on the relationship between POQ and career success, such that this effect was stronger when employees' career concern was high. 


\section{Conflicts of Interest}

The authors declare no conflicts of interest regarding the publication of this paper.

\section{References}

[1] Erdogan, B. and Bauer, T.N. (2009) Perceived Overqualification and Its Outcomes: The Moderating Role of Empowerment. Journal of Applied Psychology, 94, 557-565. https://doi.org/10.1037/a0013528

[2] Maltarich, M.A., Reilly, G. and Nyberg, A.J. (2011) Objective and Subjective Overqualification: Distinctions, Relationships, and a Place for Each in the Literature. Industrial \& Organizational Psychology, 4, 236-239. https://doi.org/10.1111/j.1754-9434.2011.01332.x

[3] Maynard, D.C., Joseph, T.A. and Maynard, A.M. (2006) Underemployment, Job Attitudes, and Turnover Intentions. Journal of Organizational Behavior, 27, 509-536. https://doi.org/10.1002/job.389

[4] Liu, S. and Wang, M. (2012) Perceived Overqualification: A Review and Recommendations for Research and Practice. Research in Occupational Stress and Well-Being, 10, 1-42. https://doi.org/10.1108/S1479-3555(2012)0000010005

[5] Zhang, M.J., Law, K.S. and Lin, B. (2016) You Think You Are Big Fish in a Small Pond? Perceived Overqualification, Goal Orientations, and Proactivity at Work. Journal of Organizational Behavior, 37, 61-84. https://doi.org/10.1002/job.2024

[6] Chudzikowski, K. (2012) Career Transitions and Career Success in the "New" Career Era. Journal of Vocational Behavior, 81, 298-306. https://doi.org/10.1016/j.jvb.2011.10.005

[7] Smith, T. and Sheridan, A. (2006) Organizational Careers versus Boundaryless Careers. Journal of Management and Organization, 12, 223-234. https://doi.org/10.1017/S1833367200003977

[8] Hobfoll, S.E. (1989) Conservation of Resources: A New Attempt at Conceptualizing Stress. American Psychologist, 44, 513-524. https://doi.org/10.1037/0003-066X.44.3.513

[9] Agut, S., Peiro, J.M. and Grau, R. (2009) The Effect of Overeducation on Job Content Innovation and Career-Enhancing Strategies among Young Spanish Employees. Journal of Career Development, 36, 159-182. https://doi.org/10.1177/0894845308327738

[10] Wang, Z. and Sun, J.M. (2012) The Impact of Core Self-Evaluation and Organizational Support on Subjective and Objective Career Success: A Perspective of $\mathrm{Hu}-$ man-Situational Interaction. Journal of Management, 9, 1307-1313. (In Chinese)

[11] Jia, W.W., Wang, Z.J., Wen, L., Zhu, X.D. and Xu, N. (2015) The Relationship between Career Success and Subjective Well-Being of Employees in Enterprises. Chinese Journal of Health P sychology, 23, 219-224. (In Chinese)

[12] Ng, T.W.H. and Feldman, D.C. (2010) Human Capital and Objective Indicators of Career Success: The Mediating Effects of Cognitive Ability and Conscientiousness. Journal of Occupational \& Organizational Psychology, 83, 207-235. https://doi.org/10.1348/096317909X414584

[13] Ren, H., Wen, Z.L. and Chen, Q.S. (2013) The Impact of Psychological Capital on Employees' Career Success: The Mediating Effect of Career Commitment. Psychological Science, 36, 194-198. (In Chinese)

[14] Maltarich, M.A., Nyberg, A.J. and Reilly, G.P. (2010) A Conceptual and Empirical Analysis of the Cognitive Ability-Voluntary Turnover Relationship. Journal of Ap- 
plied P sychology, 95, 1058-1070. https://doi.org/10.1037/a0020331

[15] Tims, M. and Bakker, A.B. (2010) Job Crafting: Towards a New Model of Individual Job Redesign. Sajip South African Journal of Industrial P sychology, 36, 1-9. https://doi.org/10.4102/sajip.v36i2.841

[16] Lepine, J.A., Podsakoff, N.P. and Lepine, M.A. (2005) A Meta-Analytic Test of the Challenge Stressor-Hindrance Stressor Framework: An Explanation for Inconsistent Relationships among Stressors and Performance. Academy of Management Journal, 48, 764-775. https://doi.org/10.5465/amj.2005.18803921

[17] Gorgievski, M.J. and Hobfoll, S.E. (2008) Work Can Burn Us out or Fire Us up: Conservation of Resources in Burnout and Engagement. In: Halbesleben, J.R.B., Ed., Handbook of Stress and Burnout in Health Care, Nova Science Publishers, Hauppauge, 7-22.

[18] Savickas, M.L. and Porfeli, E.J. (2012) Career Adapt-Abilities Scale: Construction, Reliability, and Measurement Equivalence across 13 Countries. Journal of Vocational Behavior, 80, 661-673. https://doi.org/10.1016/j.jvb.2012.01.011

[19] Savickas, M.L. (2005) The Theory and Practice of Career Construction. In: Brown, S.D. and Lent, R.W., Eds., Career Development and Counseling: Putting Theory and Research to Work, Wiley, Hoboken, 42-70.

[20] Fine, S. and Nevo, B. (2008) Too Smart for Their Own Good? A Study of Perceived Cognitive Overqualification in the Workforce. International Journal of Human Resource Management, 19, 346-355. https://doi.org/10.1080/09585190701799937

[21] Tims, M., Bakker, A.B. and Derks, D. (2012) Development and Validation of the Job Crafting Scale. Journal of Vocational Behavior, 80, 173-186.

https://doi.org/10.1016/j.jvb.2011.05.009

[22] Greenhaus, J.H., Parasuraman, S. and Wormley, W.M. (1990) Effects of Race on Organizational Experiences, Job Performance Evaluations, and Career Outcomes. Academy of Management Journal, 33, 64-86.

[23] Eby, L.T., Butts, M. and Lockwood, A. (2003) Predictors of Success in the Era of Boundaryless Careers. Journal of Organizational Behavior, 24, 689-708. https://doi.org/10.1002/job.214

[24] Hou, Z.J., Leung, S.A., Li, X., Li, X. and Xu, H. (2012) Career Adapt-Abilities Scale-China Form: Construction and Initial Validation. Journal of Vocational Behavior, 80, 686-691. https://doi.org/10.1016/j.jvb.2012.01.006

[25] Luksyte, A., Spitzmueller, C. and Maynard, D.C. (2011) Why Do Overqualified Incumbents Deviate? Examining Multiple Mediators. Journal of Occupational Health Psychology, 16, 279-296. https://doi.org/10.1037/a0022709

[26] Wu, C.H., Tian, A.W., Luksyte, A. and Spitzmueller, C. (2017) On the Association between Perceived Overqualification and Adaptive Behavior. Social Science Electronic Publishing, 46, 339-354. https://doi.org/10.1108/PR-05-2015-0134

[27] Zhou, H. and Long, L. (2004) Statistical Remedies for Common Method Biases. Advances in Psychological Science, 12, 942-950. (In Chinese)

[28] Hayes, A. (2013) Introduction to Mediation, Moderation, and Conditional Process Analysis. Journal of Educational Measurement, 51, 335-337.

[29] Erdogan, B., Bauer, T.N., Peiró, J.M. and Truxillo, D.M. (2011) Overqualification Theory, Research, and Practice: Things That Matter. Industrial \& Organizational Psychology, 4, 260-267. https://doi.org/10.1111/j.1754-9434.2011.01339.x

[30] Taber, B.J. and Blankemeyer, M. (2015) Future Work Self and Career Adaptability in the Prediction of Proactive Career Behaviors. Journal of Vocational Behavior, 86, 20-27. https://doi.org/10.1016/j.jvb.2014.10.005 